\title{
A METHOD TO PREDICT FOULING ON MULTI-STOREY BUILDING MOUNTED SOLAR PHOTOVOLTAIC PANELS: A COMPUTATIONAL FLUID DYNAMICS APPROACH
}

\author{
Kudzanayi Chiteka ${ }^{1 *}$, Rajesh Arora ${ }^{1}$, S. N. Sridhara ${ }^{2}$
}

\begin{abstract}
The influence of installation and environmental parameters on dust particle deposition behavior on solar photovoltaic collectors were investigated using Computational Fluid Dynamics (CFD) simulation. Parameters including tilt, height of installation, dust particle size and wind speed were investigated. Modeling of wind flow on the building and the photovoltaic array was achieved using the Shear Stress Transport k- $\omega$ turbulence model. The discrete phase model was adopted for dust motion prediction and a model was developed to assess the impact of dust accumulation on the performance of the photovoltaic array. The study revealed that rooftop installations have less dust deposition unlike the ground-mounted installations. The wind flow characteristics on rooftop installations are greatly affected by the building while on ground mounted installations wind flow is only influenced by the tilt of the solar photovoltaic collector. Different tilt angles, wind speeds and particle sizes had different deposition characteristics. The lower impact velocities experienced on ground mounted Photovoltaic $(\mathrm{PV})$ arrays resulted in more deposition for smaller sized $(10 \mu \mathrm{m})$ dust particles compared to the larger sized $(50 \mu \mathrm{m}$ and $150 \mu \mathrm{m}$ ) particles. On rooftop installations, dust particle size of $150 \mu \mathrm{m}$ had the most deposition at a velocity of $5 \mathrm{~m} / \mathrm{s}$ and hence it resulted in a $22.61 \%$ reduction in solar photovoltaic efficiency while the least reduction in efficiency of $1.32 \%$ was recorded at $15 \mathrm{~m} / \mathrm{s}$ and $10 \mu \mathrm{m}$ size dust particles. The tilt angles of $0^{\circ}$ and $22.5^{\circ}$ had large sized turbulent eddies compared to the tilt of $45^{\circ}$. The study revealed that ground mounted photovoltaic arrays had more dust deposition compared to rooftop mounted photovoltaics.
\end{abstract}

\section{Keywords: Solar Photovoltaics, Dust Deposition, CFD Simulation, Installation Configuration, Empirical Modelling}

\section{INTRODUCTION}

Solar energy is a developing alternative source of clean energy which has been in the picture for some decades. It is rapidly growing with more than 50\% market growth rate for solar PV in 2016 and more than $75 \mathrm{GW}$ of solar photovoltaic (PV) installed worldwide [1-4]. However, fouling also known as soiling which is the buildup of dust particles on the solar PV module is a major concern for the wider deployment of solar energy and this has attracted the attention of many researchers [5-10].

Fouling losses may range from 5\% to $70 \%$ depending on the place, climatic conditions and time of exposure [12-14]. In a study by Pavan et al. [11], which was done to evaluate fouling power losses, it was reported that for poly-crystalline PV modules power losses of between $1 \%$ and $5 \%$ are expected within a year of operation. In a different study, Adinoyi and Said [13] investigated fouling effects on PV collectors in Saudi Arabia's Eastern region for a period of six months and they recorded $50 \%$ power loss due to fouling.

El-Nashar [12] evaluated the effect of fouling on transmittance and power efficiency in the United Arab Emirates for a period of one year and the results revealed a $10 \%$ decrease in transmittance while power efficiency loss of the PV system was $70 \%$.

The installation configuration also influence fouling of PV collectors. Elminir et al. [5] explored the influence of tilt angles on fouling and transmittance and their observation revealed that higher tilt angles are associated with less fouling and hence have a higher transmittance compared to lower tilt angles. Similar investigations by Mekhilef et al. [6] confirmed the reduction in fouling with increasing tilt angle. The installation orientation in relation to wind flow was also found to affect fouling and studies have revealed that PV surfaces facing away from the wind direction experiences four times less fouling when compared to those facing the wind ward side and they have 50\% less fouling compared to horizontal surfaces [14-17]. The influence of wind velocity on fouling was also investigated by several researchers $[6,15,18,19]$ and it was found that higher wind speeds

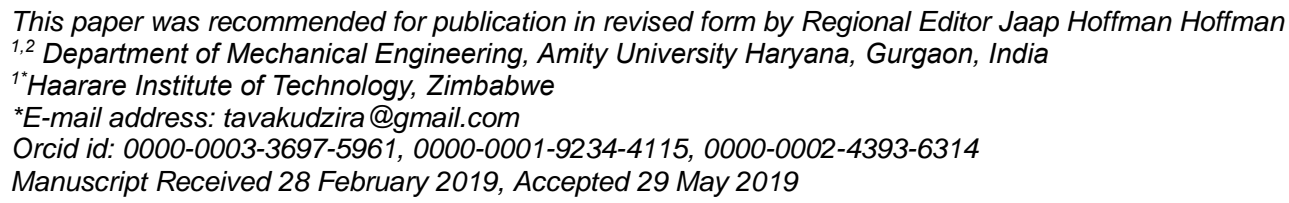


are associated with higher dust deposition. However, other researches have reported otherwise with some reports suggesting that strong winds have a cleaning effect whilst slow breezes actually promotes dust accumulation [4, $11,18]$.

Dust particle characteristics such as size and density have an effect on dust deposition behaviour on the PV collector. Studies by El-Shobokshy and Hussein [21] have indicated that smaller sized dust particles have a more detrimental effect on the PV collector efficiency when compared to large sized dust particles.

Attempts have also been made to ascertain the impact of PV module types on fouling and it was reported that there are no notable differences in fouling in different PV collectors [22].

Some fouling mitigation strategies have been suggested by several researchers [21-24] proposing novel coatings either hydrophobic or hydrophillic which they found to reduce dust deposition on PV collectors. Moghimi and Ahmadi [27] further cited the importance of minimizing soiling due to the excessive expense of cleaning requiring millions of litres of water every year.

Some studies have indicated that natural cleaning mechanisms in form of wind and rain do exist [26, 27] but the subject has not been extensively explored. Many investigations mainly concentrated on the effects of fouling on performance $[5,28,29]$. Although some few simulation studies have been done to examine fouling characteristics on PV collectors [29-32], a lot still need to be understood. For example, Moghimi and Ahmadi [27] carried out simulation studies to optimize wind barriers to minimize soiling on parabolic dish solar power plant and were able to prevent more than $86 \%$ of dust particles to settle on the collectors. In most of these studies, the effect of parameters such as tilt, wind speed, dust particle concentration and dust particle size have been studied. The characteristic behaviour of dust deposition on roof top solar PV collectors still need to be explored to devise mitigation procedures to minimise fouling while maximising the energy harvested. Rooftop solar requires special consideration as it is not easy to clean unlike ground mounted solar PV modules. CFD has proven to be a useful tool in modeling solid-gas flows and provides a platform for further optimization [33, 34]. Although CFD simulations were performed by Lu et al. [31] on rooftop solar installation, their study focused on a single storey building with inclined roof where the PV module was directly attached to the inclined roof. In their study, the airflow on the solar panel was obviously similar to that on the roof since the panel was attached directly to the roof. The wind flow and hence fouling characteristics are, however, different for flat rooftops of multi-storey buildings which have a different mounting structure. PV modules on rooftops of multi storey buildings cannot be easily cleaned and for this reason a different fouling mitigation strategy that takes cognisance of the natural mitigation agencies need to be developed based on the simulated flow and fouling characteristics. In this study, the turbulent air flow characteristic behaviour on the building together with the dust deposition phenomenon is analysed. The effect of different particle sizes, wind speeds and tilt angles are investigated in this study. Further, a method by Jiang et al [22] was employed to assess the PV efficiency dependency on fouling as a function of the time of exposure.

This study is organized as follows: Section 1 is the introduction integrated with the literature review leading to the research gap. Section 2 highlights the materials and methods used in the study with detailed equations for CFD computations. Section 3 involves a full report and discussion of the outcomes of the investigation, and lastly section 4 is the conclusion of the study.

\section{SOLUTION STRATEGY AND NUMERICAL METHODOLOGY Turbulence Modelling and Fluid Flow Analysis}

The fluid flow analysis was performed using the Reynolds Averaged Navier Stokes (RANS) governing equations. Turbulence modelling was executed using Shear Stress Transport (SST) k- $\omega$ turbulence model as this turbulence model has been found to have better performance than other RANS models on dust deposition applications and it captures the best from $\mathrm{k}-\omega$ and $\mathrm{k}-\varepsilon$ two-equation models $[32,35,36]$.

Dust motion was analysed by making use of the Discreet Phase Model (DPM) and particle-particle interactions were ignored. The DPM was employed in this study owing to its suitability in modelling two phase flow problems consisting of a single continuous phase and the discrete phase of a volume fraction less than $12 \%$. Having considered the concentration of dust particles in a normal atmosphere, it was therefore necessary to consider negligible the particle-particle interaction and that the fluid flow field was not affected by the existence 
of the particles in the atmosphere [39]. The Discreet Random Walk model (DRW) was employed in modeling the turbulent dispersion of particles to correctly envisage dust particle accumulation behavior.

The RANS governing equations were utilized in modelling fluid flow (Equation 1) [33] and these equations describes the relationship between velocity, pressure, temperature and density. The RANS equations based on the conservation laws which are conservation of energy, mass and momentum are depicted in Equations $2-4[40]$.

$$
\begin{gathered}
\rho \frac{\partial \bar{\emptyset}}{\partial t}+\rho \overline{\mathrm{u}}_{j} \frac{\partial \bar{\emptyset}}{\partial x_{j}}-\frac{\partial}{\partial x_{j}}\left[\Gamma_{\emptyset, \mathrm{eff}} \frac{\partial \bar{\emptyset}}{\partial x_{j}}\right]=S_{\emptyset} \\
\frac{\partial \rho}{\partial t}+\nabla \rho u=0 \\
\rho \frac{\mathrm{Du}_{i}}{\mathrm{Dt}}=-\frac{\partial p}{\partial x_{i}}+\frac{\partial}{\partial x_{j}}\left[\mu\left(\frac{\partial u_{i}}{\partial x_{j}}+\frac{\partial u_{j}}{\partial x_{j}}-\frac{2}{3} \frac{\partial u_{r}}{\partial x_{r}} \delta_{\mathrm{ij}}\right)\right]+\rho \mathrm{F}_{i} \\
\rho \frac{\mathrm{De}}{\mathrm{Dt}}=-p \frac{\partial u_{i}}{\partial x_{j}}+\frac{\partial u_{i}}{\partial x_{j}} \mu\left(\frac{\partial u_{i}}{\partial x_{j}}+\frac{\partial u_{j}}{\partial x_{j}}-\frac{2}{3} \frac{\partial u_{r}}{\partial x_{r}} \delta_{\mathrm{ij}}\right)+\frac{\partial}{\partial x_{i}}\left(\kappa \frac{\partial T}{\partial x_{i}}\right)
\end{gathered}
$$

where, $\rho$ is the density $\left(\mathrm{kg} / \mathrm{m}^{3}\right), \kappa$ is thermal conductivity $\left(\mathrm{Wm}^{-1} \mathrm{~K}^{-1}\right), \mathrm{t}$ is the time $(\mathrm{s}), \mathrm{u}$ is the velocity vector $\left(\mathrm{m} \cdot \mathrm{s}^{-1}\right), \Gamma \emptyset$,eff is effective diffusion coefficient $\left(\mathrm{m}^{2} / \mathrm{s}\right), \Phi$ is the independent flow variable, and $\mathrm{S}_{\Phi}$ is the source term $\left(\mathrm{kg} / \mathrm{m}^{3} \mathrm{~s}\right)$.

Turbulence modelling was attained using the SST k- $\omega$ turbulence model and it is formulated as shown in Equations 5 and 6 . This model is able to better predict the commencement and magnitude of flow separation happening at adverse pressure gradients. The model SST k- $\omega$ which was used can be described by the following equations [41],

$$
\begin{gathered}
\frac{\partial}{\partial t}(\rho \mathrm{k})+\frac{\partial}{\partial x_{i}}\left(\rho \mathrm{ku}_{i}\right)=\frac{\partial}{\partial x_{j}}\left(\Gamma_{k} \frac{\partial k}{\partial x_{j}}\right)+\tilde{G}_{k}-L_{k} \\
\frac{\partial}{\partial t}(\rho \omega)+\frac{\partial}{\partial x_{i}}\left(\rho \omega \mathrm{u}_{i}\right)=\frac{\partial}{\partial x_{j}}\left(\Gamma_{\omega} \frac{\partial \omega}{\partial x_{j}}\right)+\tilde{G}_{\omega}-L_{\omega}+K_{\omega}
\end{gathered}
$$

where, $\widetilde{G}_{\omega}$ is a generation term for specific dissipation rate $\omega\left(\mathrm{s}^{-1}\right), \widetilde{G}_{k}$ is a generation term for the turbulent kinetic energy $k\left(\mathrm{~m}^{2} / \mathrm{s}^{2}\right), \mathrm{L}_{\mathrm{k}}$ and $\mathrm{L}_{\omega}$ represents the dissipation rate of $\mathrm{k}$ and $\omega, \Gamma_{\omega}$ and $\Gamma_{\mathrm{k}}$ are the effective diffusivity of $\omega$ and $\mathrm{k}, \mathrm{K}_{\omega}$ stands for the cross-diffusion term.

\section{Dust Motion Modelling}

Dust motion was modelled using the Discreet Phase Model (DPM) and the formulation is shown in Equations 7 and 8. The interactions of dust particles with wind was taken into account in the CFD computation. The particle-particle interactions of dust particles were considered insignificant in the diluted air-dust flow with the dilution considered less than $12 \%$. In the CFD simulation, the following forces were considered, drag force, gravitational force and thermophoresis force. Equation 7 predicts dust particle motion and is given as follows [33],

$$
\begin{gathered}
\frac{\partial x_{j}^{p}}{\partial t}=u_{j}^{p} \\
\frac{\partial u_{j}^{p}}{\partial t}=\frac{1+0.15 R e_{d}^{0.687}}{\tau_{p}}\left(u_{j}^{f}-u_{j}^{p}\right)+\frac{5.188 v^{\frac{1}{2}} d_{i j}}{s d\left(d_{l k} d_{k l}\right)^{\frac{1}{4}}}\left(u_{j}^{f}-u_{j}^{p}\right)+n_{j}(t)+\left(1-\frac{1}{s}\right) g_{i}
\end{gathered}
$$

where, $\quad u_{j}^{f}=\bar{u}_{i}+u_{j}^{\prime}, \quad u_{j}^{\prime}=$ mean flow taken at the position of the particle, $d=$ diameter, $u_{j}^{\prime}=$ velocity of flow fluctuation, $x_{j}^{p}=$ position of particle; $u_{j}^{p}=$ particle center velocity, $t=$ time $(s), S=$ particle to fluid density ratio, $g_{i}=$ acceleration due to gravity, $\mathrm{Re}=$ Particles' Reynolds number.

The DRW model was employed in modelling the turbulent dispersion of dust particles to correctly predict dust particle deposition behaviour [41]. The study assumed no rebound of dust particles on the solar panel surface. Values of 0.5 and 0.55 were respectively assumed for the roughness constants $\left(C_{s}\right)$ for the PV module 
and the wall because the PV module surface is more uniform compared to the building wall. Further, a roughness length $z_{o}$ of respectively 0.0001 and 0.001 for the PV and the building wall were adopted and the formulation in Equation 9 was used to find the roughness height $k_{s}$ used for both the PV and the wall [40, 41].

$$
k_{s} C_{s}=9.793 z_{o}
$$

Wind velocities $U$, of $5 \mathrm{~m} / \mathrm{s}$ and $15 \mathrm{~m} / \mathrm{s}$ were used for wind flow velocity while the standard atmospheric pressure was used for the initial pressure. In the simulation model, the inlet wind velocity profile and the Turbulent Kinetic Energy (TKE) profile were compared to profiles obtained in wind tunnel experiments. The results are presented in Figure 1 and 2 where $\mathrm{Z}(\mathrm{m})$ is height from the ground at any particular location of interest in the computational domain and $\mathrm{K}\left(\mathrm{m}^{2} / \mathrm{s}^{2}\right)$ is turbulent kinetic energy, $\mathrm{h}(\mathrm{m})$ is the PV module height and $\mathrm{U}_{\mathrm{h}}(\mathrm{m} / \mathrm{s})$ is the speed at PV module height $\mathrm{h}$. The dust particles used were Calcium Carbonate with a density of $2800 \mathrm{~kg} / \mathrm{m}^{3}$.

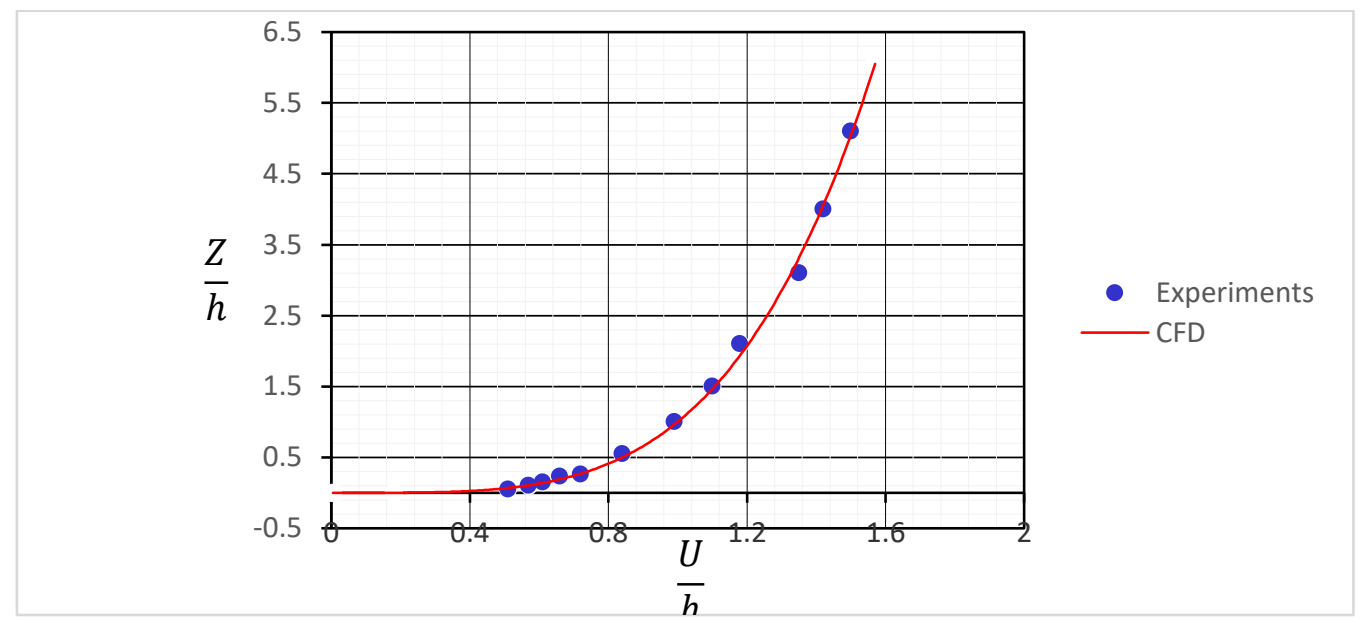

Figure 1. Wind velocity profile at inlet

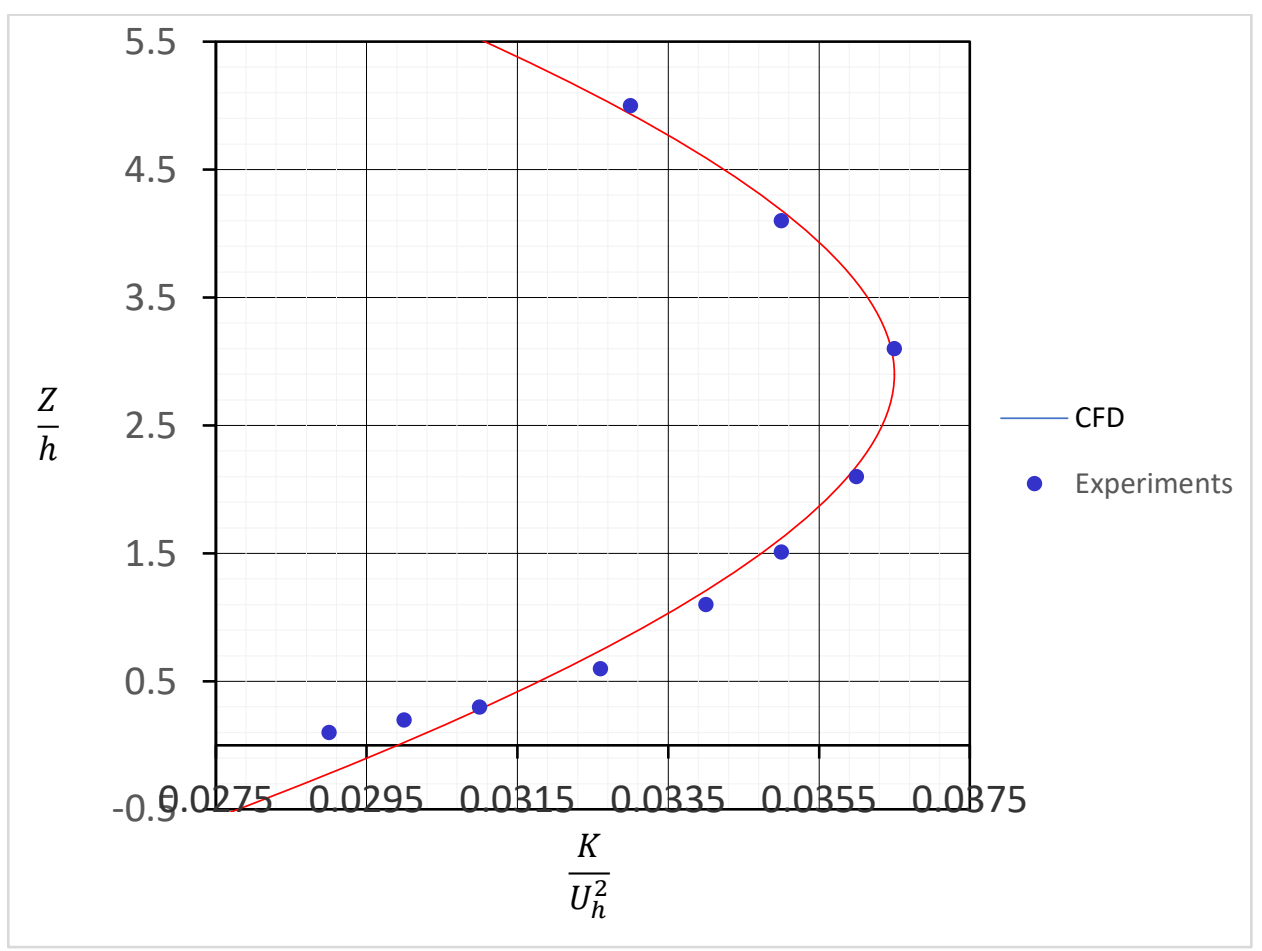

Figure 2. Turbulent Kinetic Energy (TKE) profile 


\section{Computational Domain}

The computational geometry was developed using ANSYS design Modeller 17. Figure 3 shows the schematic of the model of a 3-storey building with a rooftop solar PV array installed. The length (L), width (W) and height $(\mathrm{H})$ of the building were taken as $20 \mathrm{~m}, 15 \mathrm{~m}$ and $10 \mathrm{~m}$ respectively. The installed solar PV array had a surface area of $24 \mathrm{~m}^{2}$. The computational domain used mimicked the one used by Abiola-Ogedengbe et al. [44] in their wind tunnel experiments.

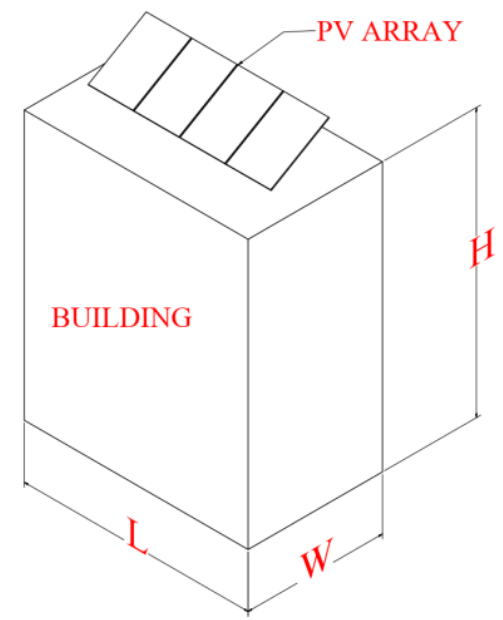

Figure 3. Schematic of the 3-storey building with a PV array installed

The tilt of the PV array was varied between $0^{\circ}, 22.5^{\circ}$ and $45^{\circ} . \mathrm{H}+0.5 \mathrm{~m}$ gave the height of the PV module $(h)$ from the ground where $\mathrm{H}$ is the height of the building thus $\mathrm{h}$ was equal to $10.5 \mathrm{~m}$. The wind velocity was varied between $5 \mathrm{~m} / \mathrm{s}$ and $15 \mathrm{~m} / \mathrm{s}$ while the dust particle sizes used were $10 \mu \mathrm{m}, 50 \mu \mathrm{m}$ and $150 \mu \mathrm{m}$. The computational domain had its length, height and width of $21.4 h, 6 h$ and $9 h$ respectively corresponding to $224.7 \mathrm{~m}, 63 \mathrm{~m}$ and $94.5 \mathrm{~m}$. The distance between the computational inlet and the building was $5 h(52.5 \mathrm{~m})$ and the distance behind the PV module was $15 h(157.5 \mathrm{~m})$. These dimensions made sure that the channel wall boundary layers do not obstruct air flow on the PV module surface.

ANSYS ICEM 17 was used to develop structured grids with 495618 nodes. The computational domain was open in all sides and had different zones including the inlet, the building, the solar PV array and the outlet. The solar PV array is fixed on top of the building and a no slip condition is assumed. The boundary condition for the inlet consists of a velocity inlet with a velocity large enough to achieve a Reynolds's number greater than 100 000 to achieve turbulent flow.

The Finite Volume Method (FVM) was utilized in resolving the conservation equations of wind flow while the pressure and velocity fields were decoupled using the SIMPLE algorithm. The diffusion and convection terms were discretized making use of the second-order upwind scheme as shown in Equation 10 [45]. To resolve the dust particles', motion equations, the Runge-Kutta technique was adopted. The Solution was considered to be converged when the Residual Mean Square Error (RMSE) value of $10^{-6}$ was attained for the fine mesh selected.

$$
\emptyset_{f}, S O U=\emptyset+\nabla \emptyset \cdot \vec{r}
$$

where, $\emptyset_{\mathrm{f}}$, SOU is the face value (using second order upwind, SOU), $\overrightarrow{\mathrm{r}}$ is the displacement vector from the upstream cell centroid to the face centroid, $\emptyset \& \nabla \emptyset$ are the cell-cantered value and its gradient in the upstream cell.

\section{Grid Independence}

The minimum grid size that gives the best results was determined using the grid independence study and three grids were identified in the study as coarse (52 059), medium (190 918), and fine (495 618) were used in the study. The quantity of particles deposited on the solar PV module for each mesh size was noted and a comparison of the different mesh sizes was carried out. The results showed that that the percentage difference on the deposition 
rate for the coarse and medium meshes compared to the fine mesh was respectively $39 \%$ and $8 \%$. It was therefore established that a fine mesh was the most desirable in giving accurate results. Air flow fields near the PV module were simulated to evaluate the fouling on the solar PV collector. The simulations were validated using experimental data by Abiola-Ogedengbe's et al. [44] results of wind tunnel experiments as shown in Figure 5, where, $w$ represents the distance measured along the solar panel width from the leading edge and $\mathrm{W}_{\mathrm{p}}$ is solar panel width. The results verified that the pressure coefficient $\left(\mathrm{C}_{\mathrm{p}}\right)$ profile correctly followed the experimental data and hence it was established that the CFD model was capable of accurately calculating air flow fields around the solar PV module.

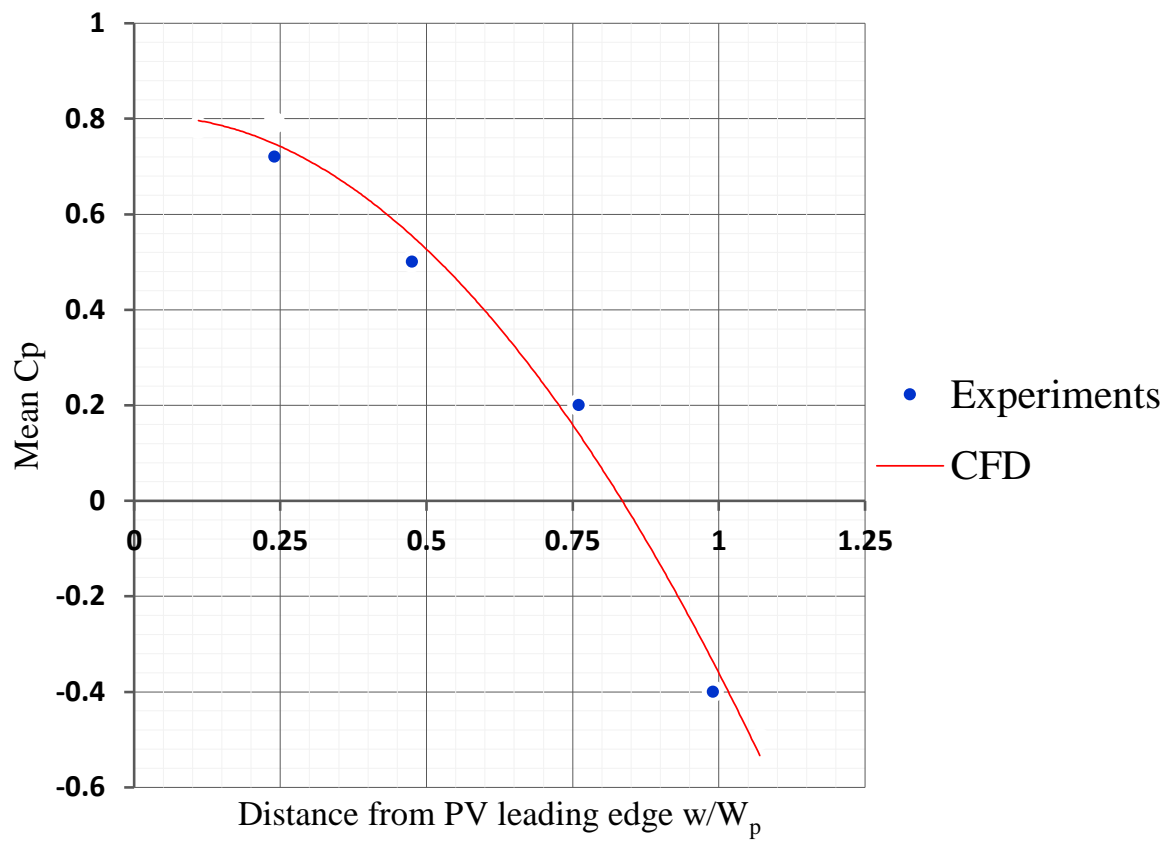

Figure 4. Experimental validation of the mean pressure coefficient $(\mathrm{Cp})$

\section{RESULTS AND DISCUSSIONS \\ Experimental Design}

The influence of different particle sizes, wind speeds and tilt angles were investigated in this study using CFD. Wind flow characteristics were predicted by solving the RANS equations with the turbulence model SST k$\omega$ being used to resolve wind flow turbulence in the vicinity of the PV collector. The DPM model was used in trajectory tracking of dust particles and the DRW model was employed to model the turbulent dispersion. Software Fluent v.17 was used in the simulation process.

\section{Dust Deposition and Wind Flow Fields on PV Module}

The fouling rates and behaviour were computed using the characteristic wind flow fields on the solar PV array. The simulations revealed that at elevated places such as rooftops of high rise buildings, the wind flow and hence the fouling characteristics are completely different from ground mounted PV collectors. The velocity contours shown in Figure 5 indicates that the maximum wind speed experienced on ground mounted PV collectors is lower than the wind velocity acting on rooftop PV collectors. This scenario is due to the effect of surface roughness of the ground which significantly reduces the wind velocity near the ground [46]. Frictional resistance affects airflow near the ground and hence its velocity is reduced a phenomenon known as wind shear. Equation 11 [47] explains the variation of wind velocity with height where $V_{z}$ is the wind velocity at height $z, V$ is the characteristic speed, $z_{o}$ is the roughness length and $d$ is the zero plane displacement and it value is slightly less than the height of the local obstructions. 


$$
V_{z}=V \ln \left(\frac{z-d}{z_{o}}\right)
$$
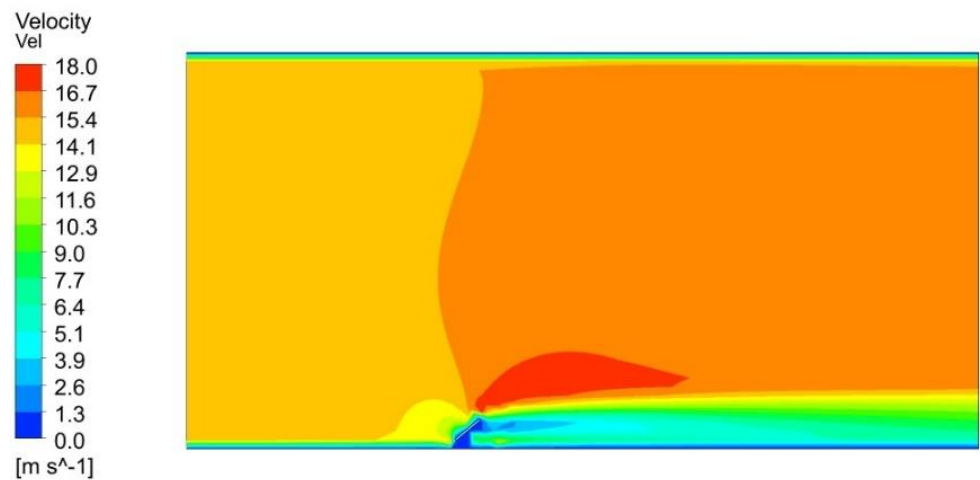

a) Ground mounted $\left(45^{\circ}\right), 15 \mathrm{~m} / \mathrm{s}$
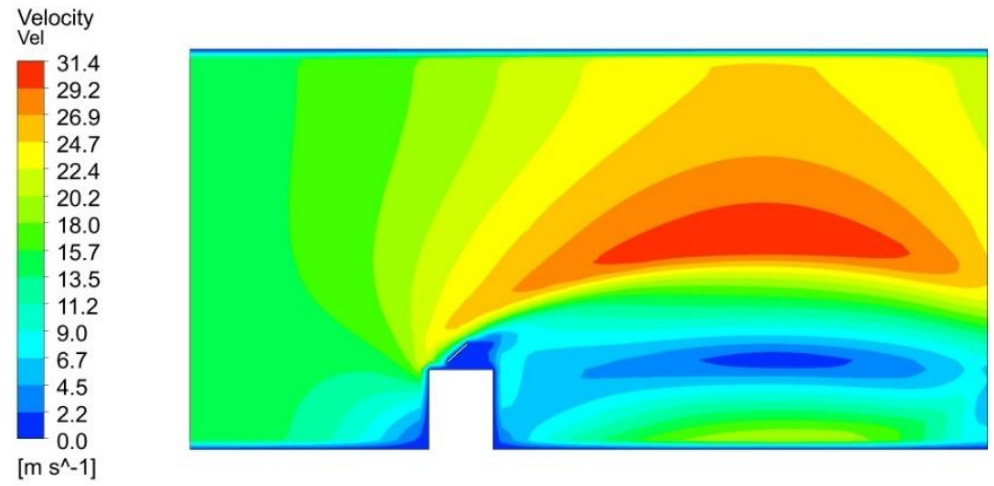

b) Roof mounted $\left(45^{\circ}\right), 15 \mathrm{~m} / \mathrm{s}$

Figure 5. Wind flow characteristics of a) ground mounted, and b) rooftop PV collector

Figure 6. a)-d) depicts the velocity fields near the PV collector at varying tilt angles. The velocity fields are very complicated due to the existence of the solar PV collector as a barrier to wind flow a phenomenon also noted by Lu and Zhao [35]. The velocity fields for all the configurations have very small differences and are almost identical for the three different tilt angles as given in Figure 6 a) -d). The huge similarity is due to high rise building having much influence on wind flow due to its bigger relative size compared to the PV array used in the simulation. As such, the wind flow characteristics and hence the dust deposition characteristics on the rooftop mounted PV collectors are dependent on those slight differences observed on the wind flow profiles.

As shown in Figure 5, there are regions of high velocity around the ground mounted horizontal PV module unlike the roof mounted PV module, which is surrounded by a region of very low velocity. This could be the reason for more fouling recorded on a ground mounted PV module compared to the roof mounted PV module. 

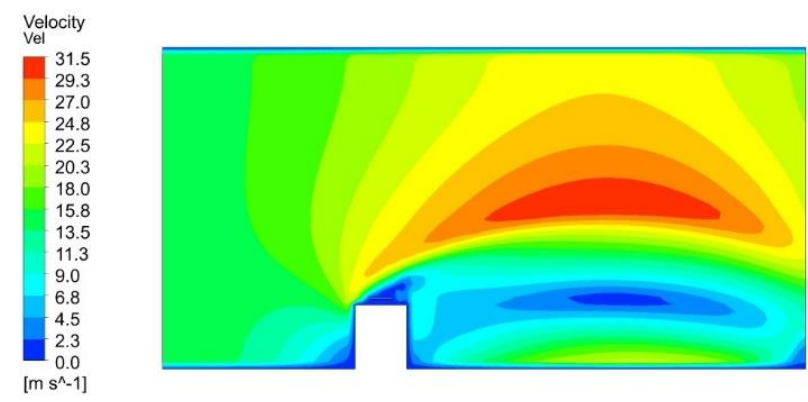

a) $0^{\circ}, 15 \mathrm{~m} / \mathrm{s}$

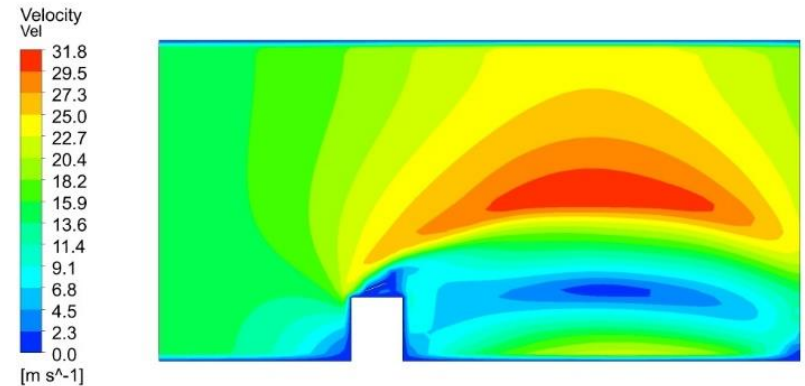

b) $22.5^{\circ}, 15 \mathrm{~m} / \mathrm{s}$

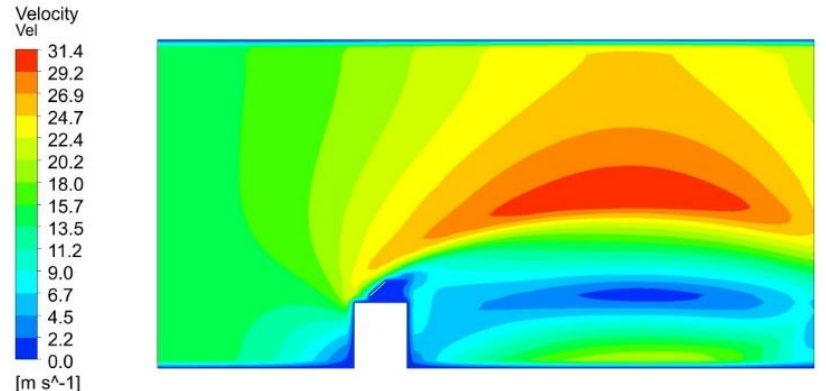

c) $45^{\circ}, 15 \mathrm{~m} / \mathrm{s}$
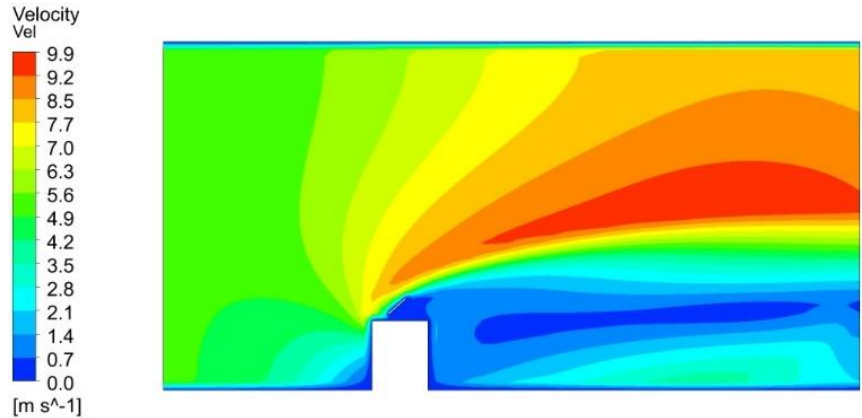

d) $45^{\circ}, 5 \mathrm{~m} / \mathrm{s}$

Figure 6. Velocity fields around the PV collector: a) $\left.\left.0^{\circ}, 15 \mathrm{~m} / \mathrm{s} \mathrm{b}\right) 22.5^{\circ}, 15 \mathrm{~m} / \mathrm{s} \mathrm{c}\right) 45^{\circ}, 15 \mathrm{~m} / \mathrm{s}$ d) $45^{\circ}, 5$ $\mathrm{m} / \mathrm{s}$

As indicated in Figure 6, the velocity fields around the PV collector are almost identical regardless of the tilt angle used for the PV array. The deposition characteristics based on impact velocity were analyzed and they agreed well with the results by Klinkov et al. [48] and these results are depicted in Figure 7. Different tilt angles had particle deposition dependent on particle size. Particles of $10 \mu \mathrm{m}$ deposited more on the horizontal and $22.5^{\circ}$ tilt angles at impact velocities between $4.5 \mathrm{~m} / \mathrm{s}$ and $9.1 \mathrm{~m} / \mathrm{s} .50 \mu \mathrm{m}$ and $150 \mu \mathrm{m}$ particles had almost similar deposition characteristics. More of these particles were deposited on the $45^{\circ}$ tilt angle at impact velocities between $0.7 \mathrm{~m} / \mathrm{s}$ and $9.0 \mathrm{~m} / \mathrm{s}$. 
The wind velocity of $5 \mathrm{~m} / \mathrm{s}$ had a significantly more dust deposition than a wind velocity of $15 \mathrm{~m} / \mathrm{s}$ for dust particle sizes of $50 \mu \mathrm{m}$ and $150 \mu \mathrm{m}$. For the velocity of $5 \mathrm{~m} / \mathrm{s}$ the impact velocity was found to be in the range $1.4 \mathrm{~m} / \mathrm{s}-4.2 \mathrm{~m} / \mathrm{s}$ as shown in Figure $6 \mathrm{~d}$ ). There was an average deposition of at least $11 \%$ more for $5 \mathrm{~m} / \mathrm{s}$ compared to the average deposition for $15 \mathrm{~m} / \mathrm{s}$ wind velocity for particle sizes of $150 \mu \mathrm{m}$ for all tilt angles with $28 \%$ more deposition being recorded on the $0^{\circ}$ tilt at an impact velocity of $2.3 \mathrm{~m} / \mathrm{s}$ as in Figure 6 a).

Although reference is made to the velocities of $5 \mathrm{~m} / \mathrm{s}$ and $15 \mathrm{~m} / \mathrm{s}$, it is the impact velocities resulting from these velocities that is important for the tilted surfaces being studied. The normal velocity component to the surface should equal the threshold impact velocity for particle adhesion and influence of oblique impact on surfaces on particle fate was also reported elsewhere [25, 47].

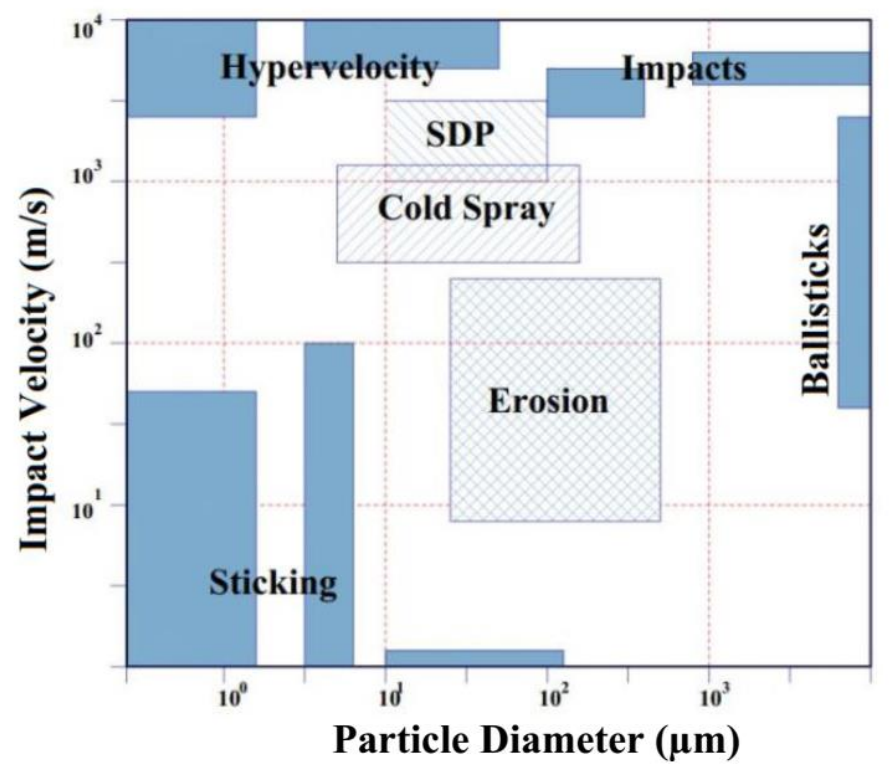

Figure 7. Particle characteristics as influenced by particle size and impact velocity

The fate of dust particles on a surface is affected by several factors including the angle of incidence and the properties of the materials used in the study [50]. Oblique angle of incidence result in different characteristics of dust particle deposition when compared to normal angles of incidence [49]. It should also be noted that the force of gravity also affects deposition where heavier particles tend to be deposited faster than light particles which may remain suspended in air for a longer time [51].

The Turbulent Kinetic Energy (TKE) profiles for the three tilt angles used for roof-mounted PV collectors are illustrated in Figure 8. The TKE profiles are almost similar for all tilt angles although a slight difference exist for the $45^{\circ}$ tilt angle where their initial occurrence is behind the PV module unlike other tilts indicating the little influence of tilt angle on wind flow on rooftop PV modules.

Airflow streamlines over the PV collector are shown in Figure 9 and turbulent eddies occurred away from the PV module vicinity behind the building. Streamlines represent the path followed by particles suspended in the fluid and they describe flow in terms of velocity and direction. The spacing between the streamlines is inversely proportional to the flow velocity.

The installation tilt angle on rooftop mounted PV collector seemed to have a slight influence on the location of occurrence and size of the turbulent eddies behind the building. The tilt angles of $0^{\circ}$ and $22.5^{\circ}$ had large sized turbulent eddies compared to the tilt of $45^{\circ}$. Comparison of ground mounted and roof mounted PV collectors indicated that there was more deposition on ground mounted collectors for all particle sizes although particles of $150 \mu \mathrm{m}$ had more deposition. Similar results were also reported in a study by Lu and Zhao [51] on their evaluation of the effects of particle sizes on deposition characteristics. The reason for lower deposition rates for roof mounted collectors compared to ground mounted collectors could be attributed to the location of the turbulent eddies on these PV collectors. Comparison of rooftop and ground mounted PV collectors shows that there is a relatively broader spectrum of impact velocity on ground mounted PV collectors as shown in Figure 5(a). This prompted more deposition of dust particles especially those of $10 \mu \mathrm{m}$ size which agrees well with the results obtained elsewhere [48]. 


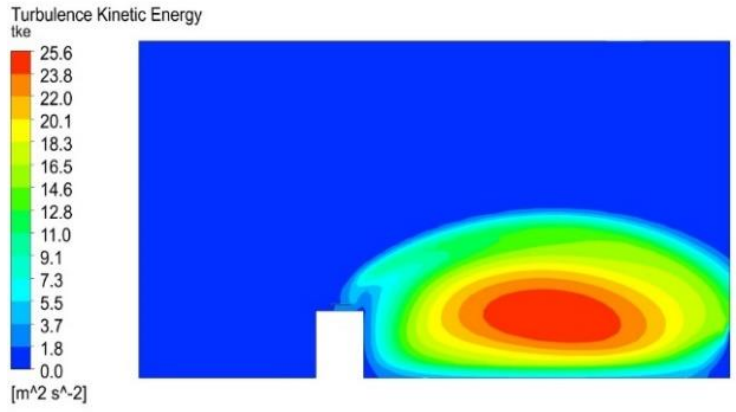

a) $0^{\circ}, 15 \mathrm{~m} / \mathrm{s}$

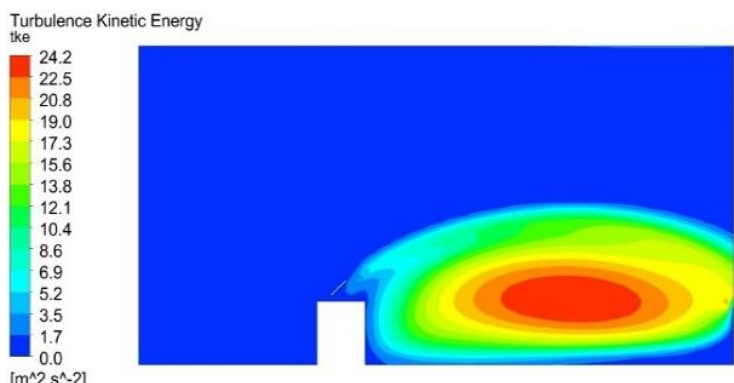

c) $45^{\circ}, 15 \mathrm{~m} / \mathrm{s}$

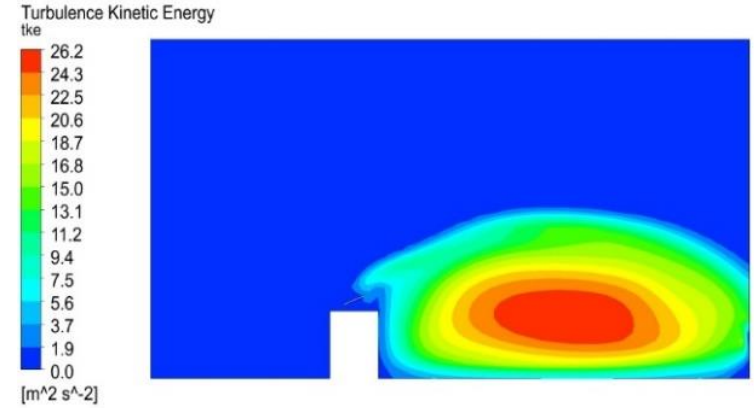

b) $22.5^{\circ}, 15 \mathrm{~m} / \mathrm{s}$

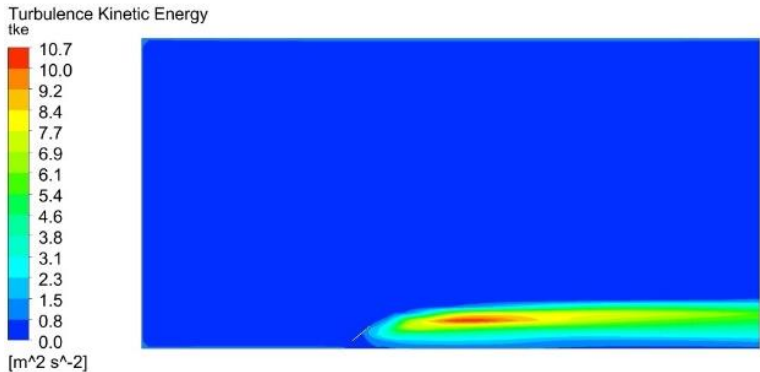

d) $45^{\circ}, 15 \mathrm{~m} / \mathrm{s}$, ground mounted

Figure 8. TKE profiles for the three different configurations: a) $0^{\circ}, 15 \mathrm{~m} / \mathrm{s}$, b) $22.5^{\circ}, 15 \mathrm{~m} / \mathrm{s}$, c) $45^{\circ}$, $15 \mathrm{~m} / \mathrm{s}, \mathrm{d}) 45^{\circ}, 15 \mathrm{~m} / \mathrm{s}$, ground mounted
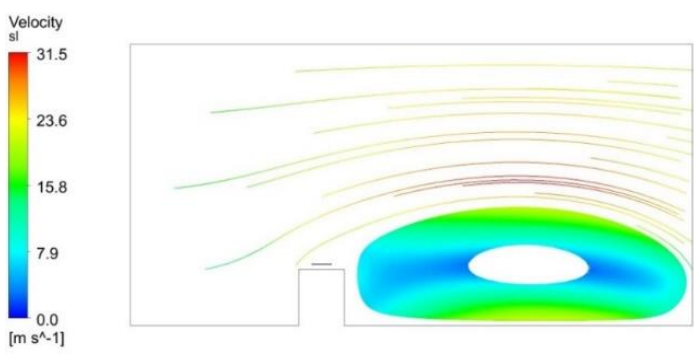

a) $0^{\circ}, 15 \mathrm{~m} / \mathrm{s}$

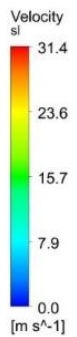

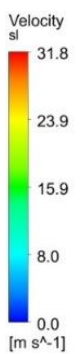

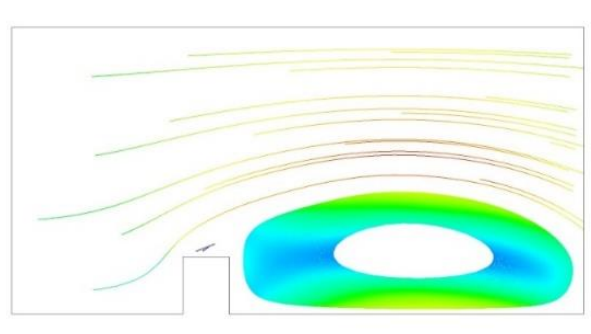

b) $22.5^{\circ}, 15 \mathrm{~m} / \mathrm{s}$
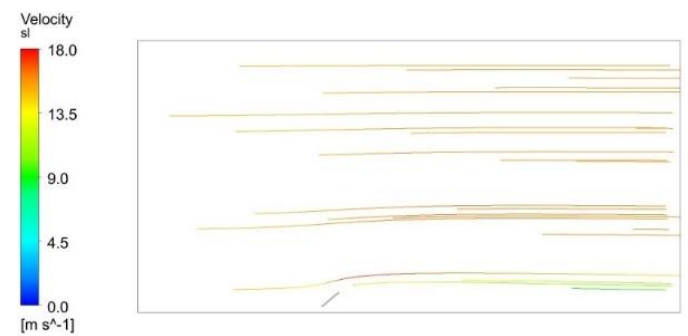

d) $45^{\circ}, 15 \mathrm{~m} / \mathrm{s}$, ground mounted

c) $45^{\circ}, 15 \mathrm{~m} / \mathrm{s}$

Figure 9. Velocity streamlines for the three tilt angles: a) $0^{\circ}, 15 \mathrm{~m} / \mathrm{s}$, b) $22.5^{\circ}, 15 \mathrm{~m} / \mathrm{s}$, c) $45^{\circ}, 15 \mathrm{~m} / \mathrm{s}$, d) $45^{\circ}, 15 \mathrm{~m} / \mathrm{s}$, ground mounted 


\section{Dependency of PV Module Efficiency on Dust Deposition}

Empirical relationships established from experimental and simulation studies by Jiang et al. [22] (Equation 12) and Lu et al. [32] (Equation 13) together with the CFD simulations in this study were used to analyze and model the effects of fouling on the efficiency of the PV collector.

$$
\begin{aligned}
& \frac{\eta_{s}}{\eta_{c}}=\lambda \rho \\
& \eta_{s}=\pi \lambda \delta T \frac{N \rho \phi^{3}}{6 t A} \times 100 \%
\end{aligned}
$$

where, $\eta_{\mathrm{s}}$ is the efficiency with fouling and $\eta_{\mathrm{c}}$ is the efficiency without fouling, while $\lambda$ and $\rho\left(\mathrm{kg} / \mathrm{m}^{3}\right)$ are respectively the fitting factor and the density of the deposited dust. $\lambda$ was taken as 0.0139 for the monocrystalline $\mathrm{PV}$ modules used as determined from experimentation [22]. $\delta, \phi(\mathrm{m})$ and $\mathrm{T}$ (days) are respectively representing the deposition rate, the particle diameter, exposure time taken as 7 days. $\mathrm{N}$ is the number of particles introduced in time $\mathrm{t}$ taken as 1000 per second and A is the PV module's surface area.

Table 1. Relationship between dust deposition and efficiency of the PV array

\begin{tabular}{|c|c|c|c|c|}
\hline $\begin{array}{c}\mathbf{D} \\
(\boldsymbol{\mu m})\end{array}$ & $\begin{array}{c}\text { Velocity } \\
(\mathbf{m} / \mathbf{s})\end{array}$ & $\begin{array}{c}\text { Tilt } \\
\left(\mathbf{(}^{\mathbf{}}\right)\end{array}$ & $\begin{array}{c}\text { Particles } \\
\text { Deposited } \\
\left(\mathbf{x 1 0}^{\mathbf{9}}\right)\end{array}$ & $\begin{array}{c}\text { Efficiency } \\
(\mathbf{\%})\end{array}$ \\
\hline 10 & 5 & 45 & 6 & 2.31 \\
\hline 50 & 5 & 45 & 107.8 & 12.50 \\
\hline 150 & 5 & 45 & 320 & 22.61 \\
\hline 10 & 15 & 45 & 1.2 & 1.32 \\
\hline 50 & 15 & 45 & 66 & 9.58 \\
\hline 150 & 15 & 45 & 215 & 17.67 \\
\hline 10 & 15 & $\begin{array}{c}45 \\
\text { (ground }\end{array}$ & 35 & 13.48 \\
\hline & & mounted) & & \\
\hline
\end{tabular}

An evaluation of the impact of dust particle size, flow velocity and PV tilt angle was carried out. The results indicated that the tilt angle on roof mounted PV modules had little influence on dust deposition compared to ground mounted PV modules and hence its influence on efficiency was small. However, flow velocity and dust particle size had a significant influence. The results in Table 1 shows that there was more deposition at lower velocities compared to higher velocities while large particle sizes had more deposition. It was therefore shown in this study, that on rooftop solar PV arrays, the flow impact velocity and particle sizes rather than the installation configuration mainly control the dust deposition.

\section{CONCLUSIONS}

The turbulent air flow characteristic behaviour on a multistorey building together with the dust deposition phenomenon were analysed in this study using CFD. The effect of varying sizes of dust particles, wind speeds and tilt angles were investigated and a model was developed to assess the influence of fouling on solar PV efficiency as a function of dust particle size and time of exposure. In this study, the following observations were reported:

The grid independency study established that a fine mesh was the most desirable in giving accurate results and it had $8 \%$ difference in the amount of particles accumulated compared to a medium sized mesh.

At elevated places such as rooftops of high-rise buildings, the wind flow and hence the fouling characteristics are completely different from ground mounted PV collectors. The maximum wind speed 
experienced on ground mounted PV collectors is lower than the wind velocity acting on rooftop PV collectors. This has a significant effect on dust deposition characteristics and ground mounted PV collectors have more dust deposition. The relatively lower impact velocities experienced on ground mounted PV collectors cause more dust deposition for particle sizes of $10 \mu \mathrm{m}$ leading to a $13.48 \%$ drop in efficiency.

The velocity fields for all the configurations on rooftop solar PV collectors have very small differences and are almost identical. The huge similarity is due to high rise building having much influence on wind flow due to its bigger relative size compared to the PV array size used in the simulation.

Dust deposition is more dependent on wind impact velocity and particle size. The wind velocity of $5 \mathrm{~m} / \mathrm{s}$ had a significantly more dust deposition than a wind velocity of $15 \mathrm{~m} / \mathrm{s}$ with the average deposition of at least $11 \%$ more for $5 \mathrm{~m} / \mathrm{s}$ compared to the average deposition for $15 \mathrm{~m} / \mathrm{s}$ wind velocity.

The particles with diameter of $150 \mu \mathrm{m}$ had more deposition compared to other dust particle sizes at lower impact velocities. This phenomenon is attributed to inertia and the force of gravity where heavier particles tend to be deposited faster than light particles, which may remain suspended in air for a longer time.

\section{NOMENCLATURE}

$\rho \quad$ density, $\mathrm{kg} / \mathrm{m}^{3}$

t time, $\mathrm{s}$

$\kappa \quad$ thermal conductivity, $\mathrm{Wm}^{-1} \mathrm{~K}^{-1}$

u velocity vector, $\mathrm{m} \cdot \mathrm{s}^{-1}$

$\Gamma \emptyset_{\text {,eff }} \quad$ effective diffusion coefficient, $\mathrm{m}^{2} / \mathrm{s}$

$\Phi \quad$ independent flow variable

$\mathrm{S}_{\Phi} \quad$ source term, $\mathrm{kg} / \mathrm{m}^{3} \mathrm{~s}$

$\tilde{\mathrm{G}}_{\omega} \quad$ generation term for specific dissipation rate, $\omega \mathrm{s}^{-1}$

$\tilde{\mathrm{G}}_{\mathrm{k}} \quad$ generation term for turbulent kinetic energy $\mathrm{k}, \mathrm{m}^{2} / \mathrm{s}^{2}$

$\mathrm{L}_{\mathrm{k}} \quad$ dissipation rate of, $\mathrm{k}$

$\mathrm{L}_{\omega} \quad$ dissipation rate of, $\omega$

$\Gamma_{\omega} \quad$ the effective diffusivity of, $\omega$

$\Gamma_{\mathrm{k}}$ the effective diffusivity of, $\mathrm{k}$

$\mathrm{K}_{\omega} \quad$ cross-diffusion term

d diameter, $\mathrm{m}$

$\mathrm{S} \quad$ particle to fluid density ratio

$\mathrm{g}_{\mathrm{i}} \quad$ gravitational acceleration, $\mathrm{m} / \mathrm{s}^{2}$

$\mathrm{Re} \quad$ Particles' Reynolds number

$U$ Wind velocity, $\mathrm{m} / \mathrm{s}$

$\mathrm{Cp} \quad$ pressure coefficient

$\eta_{\mathrm{s}} \quad$ power efficiency with fouling, $\%$

$\eta_{\mathrm{c}} \quad$ power efficiency without fouling, $\%$

$\lambda$ fitting factor

$\delta$ deposition rate, particles/day

\section{REFERENCES}

[1] S. A. M. Said, "Effects of dust accumulation on performances of thermal and photovoltaic flat-plate collectors," Applied Energy, vol. 37, no. 1, pp. 73-84, Jan. 1990, doi: 10.1016/0306-2619(90)90019-A.

[2] R. Siddiqui and U. Bajpai, Deviation in the performance of Solar Module under Climatic parameter as Ambient Temperature and Wind Velocity in Composite Climate, vol. 2. 2012.

[3] T. Sarver, A. Al-Qaraghuli, and L. L. Kazmerski, "A comprehensive review of the impact of dust on the use of solar energy: History, investigations, results, literature, and mitigation approaches," Renewable and Sustainable Energy Reviews, vol. 22, pp. 698-733, 2013, doi: 10.1016/j.rser.2012.12.065.

[4] Y. Jiang, L. Lu, A. R. Ferro, and G. Ahmadi, "Analyzing wind cleaning process on the accumulated dust on solar photovoltaic (PV) modules on flat surfaces," Solar Energy, vol. 159, no. April 2017, pp. 10311036, 2018, doi: 10.1016/j.solener.2017.08.083. 
[5] H. K. Elminir, A. E. Ghitas, R. H. Hamid, F. El-Hussainy, M. M. Beheary, and K. M. Abdel-Moneim, "Effect of dust on the transparent cover of solar collectors," Energy Conversion and Management, vol. 47, no. 18-19, pp. 3192-3203, 2006, doi: 10.1016/j.enconman.2006.02.014.

[6] S. Mekhilef, R. Saidur, and M. Kamalisarvestani, "Effect of dust, humidity and air velocity on efficiency of photovoltaic cells," Renewable and Sustainable Energy Reviews, vol. 16, no. 5, pp. 2920-2925, 2012, doi: 10.1016/j.rser.2012.02.012.

[7] C. Chen, H. Chen, C. H. Hsueh, and M. Chang, "Photovoltaic module performance and soiling analysis for field environment," 2015 IEEE 42nd Photovoltaic Specialist Conference, PVSC 2015, no. 1, 2015, doi: 10.1109/PVSC.2015.7355983.

[8] A. Baras, R. K. Jones, A. Alqahtani, M. Alodan, and K. Abdullah, "Measured soiling loss and its economic impact for PV plants in central Saudi Arabia," in 2016 Saudi Arabia Smart Grid (SASG), Jeddah, Saudi Arabia, Dec. 2016, pp. 1-7, doi: 10.1109/SASG.2016.7849657.

[1] S. A. M. Said, "Effects of dust accumulation on performances of thermal and photovoltaic flat-plate collectors," Applied Energy, vol. 37, no. 1, pp. 73-84, Jan. 1990, doi: 10.1016/0306-2619(90)90019-A.

[2] R. Siddiqui and U. Bajpai, Deviation in the performance of Solar Module under Climatic parameter as Ambient Temperature and Wind Velocity in Composite Climate, vol. 2. 2012.

[3] T. Sarver, A. Al-Qaraghuli, and L. L. Kazmerski, "A comprehensive review of the impact of dust on the use of solar energy: History, investigations, results, literature, and mitigation approaches," Renewable and Sustainable Energy Reviews, vol. 22, pp. 698-733, 2013, doi: 10.1016/j.rser.2012.12.065.

[4] Y. Jiang, L. Lu, A. R. Ferro, and G. Ahmadi, "Analyzing wind cleaning process on the accumulated dust on solar photovoltaic (PV) modules on flat surfaces," Solar Energy, vol. 159, no. April 2017, pp. 10311036, 2018, doi: 10.1016/j.solener.2017.08.083.

[5] H. K. Elminir, A. E. Ghitas, R. H. Hamid, F. El-Hussainy, M. M. Beheary, and K. M. Abdel-Moneim, "Effect of dust on the transparent cover of solar collectors," Energy Conversion and Management, vol. 47, no. 18-19, pp. 3192-3203, 2006, doi: 10.1016/j.enconman.2006.02.014.

[6] S. Mekhilef, R. Saidur, and M. Kamalisarvestani, "Effect of dust, humidity and air velocity on efficiency of photovoltaic cells," Renewable and Sustainable Energy Reviews, vol. 16, no. 5, pp. 2920-2925, 2012, doi: 10.1016/j.rser.2012.02.012.

[7] C. Chen, H. Chen, C. H. Hsueh, and M. Chang, "Photovoltaic module performance and soiling analysis for field environment," 2015 IEEE 42nd Photovoltaic Specialist Conference, PVSC 2015, no. 1, 2015, doi: 10.1109/PVSC.2015.7355983.

[8] A. Baras, R. K. Jones, A. Alqahtani, M. Alodan, and K. Abdullah, "Measured soiling loss and its economic impact for PV plants in central Saudi Arabia," in 2016 Saudi Arabia Smart Grid (SASG), Jeddah, Saudi Arabia, Dec. 2016, pp. 1-7, doi: 10.1109/SASG.2016.7849657.

[9] R. Appels et al., "Effect of soiling on photovoltaic modules," Solar Energy, vol. 96, pp. 283-291, 2013, doi: 10.1016/j.solener.2013.07.017.

[10] K. Chiteka, R. Arora, S. N. Sridhara, and C. C. Enweremadu, "Optimizing wind barrier and photovoltaic array configuration in soiling mitigation," Renewable Energy, vol. 163, pp. 225-236, Jan. 2021, doi: 10.1016/j.renene.2020.08.155.

[11] A. M. Pavan, A. Mellit, D. De Pieri, and S. A. Kalogirou, "A comparison between BNN and regression polynomial methods for the evaluation of the effect of soiling in large scale photovoltaic plants," Applied Energy, vol. 108, pp. 392-401, Aug. 2013, doi: 10.1016/j.apenergy.2013.03.023.

[12] A. M. El-Nashar, "The effect of dust accumulation on the performance of evacuated tube collectors," Solar Energy, vol. 53, no. 1, pp. 105-115, Jul. 1994, doi: 10.1016/S0038-092X(94)90610-6.

[13] M. J. Adinoyi and S. A. M. Said, "Effect of dust accumulation on the power outputs of solar photovoltaic modules," Renewable Energy, vol. 60, pp. 633-636, 2013, doi: 10.1016/j.renene.2013.06.014 Technical note.

[14] I. I. Mailuha JT, Murase H, "Knowledge engineering-based studies on solar energy utilization in Kenya," Agriculture Mechanization in Asia, Africa, and Latin America, vol. 25, pp. 13-6, 1994.

[15] D. Goossens, Z. Y. Offer, and A. Zangvil, "Wind tunnel experiments and field investigations of eolian dust deposition on photovoltaic solar collectors," Solar Energy, vol. 50, no. 1, pp. 75-84, 1993, doi: 10.1016/0038-092X(93)90009-D.

[16] M. Mani and R. Pillai, "Impact of dust on solar photovoltaic (PV) performance: Research status, challenges and recommendations," Renewable and Sustainable Energy Reviews, vol. 14, no. 9, pp. 3124-3131, 2010, doi: 10.1016/j.rser.2010.07.065.

[17] K. Chiteka, R. Arora, and V. Jain, "CFD Prediction of dust deposition and installation parametric optimisation for soiling mitigation in non-tracking solar PV modules," International Journal of Ambient Energy, pp. 1-14, Mar. 2019, doi: 10.1080/01430750.2019.1594373. 
[18] J. K. Kaldellis and M. Kapsali, "Simulating the dust effect on the energy performance of photovoltaic generators based on experimental measurements," Energy, vol. 36, no. 8, pp. 5154-5161, Aug. 2011, doi: 10.1016/j.energy.2011.06.018.

[19] K. Chiteka, S. N. Sridhara, and R. Arora, "Numerical investigation of installation and environmental parameters on soiling of roof-mounted solar photovoltaic array," Cogent Engineering, vol. 6, no. 1, Jul. 2019, doi: 10.1080/23311916.2019.1649007.

[20] M. R. Maghami, H. Hizam, C. Gomes, M. A. Radzi, M. I. Rezadad, and S. Hajighorbani, "Power loss due to soiling on solar panel: A review," Renewable and Sustainable Energy Reviews, vol. 59, pp. 1307-1316, 2016, doi: 10.1016/j.rser.2016.01.044.

[21] M. S. El-Shobokshy and F. M. Hussein, "Effect of dust with different physical properties on the performance of photovoltaic cells," Solar Energy, vol. 51, no. 6, pp. 505-511, Dec. 1993, doi: 10.1016/0038-092X(93)90135-B.

[22] H. Jiang, L. Lu, and K. Sun, "Experimental investigation of the impact of airborne dust deposition on the performance of solar photovoltaic (PV) modules," Atmospheric Environment, vol. 45, no. 25, pp. 42994304, 2011, doi: 10.1016/j.atmosenv.2011.04.084.

[23] M. Piliougine et al., "Comparative analysis of energy produced by photovoltaic modules with anti-soiling coated surface in arid climates," Applied Energy, vol. 112, pp. 626-634, 2013, doi: 10.1016/j.apenergy.2013.01.048.

[24] T. Lorenz, E. Klimm, and K.-A. Weiss, "Soiling and Anti-soiling Coatings on Surfaces of Solar Thermal Systems - Featuring an Economic Feasibility Analysis,” Energy Procedia, vol. 48, pp. 749-756, Jan. 2014, doi: 10.1016/j.egypro.2014.02.087.

[25] M. A. M. L. de Jesus, G. Timò, C. Agustín-Sáenz, I. Braceras, M. Cornelli, and A. de M. Ferreira, “Antisoiling coatings for solar cell cover glass: Climate and surface properties influence," Solar Energy Materials and Solar Cells, vol. 185, pp. 517-523, Oct. 2018, doi: 10.1016/j.solmat.2018.05.036.

[26] G. Polizos et al., "Anti-soiling and highly transparent coatings with multi-scale features," Solar Energy Materials and Solar Cells, vol. 188, pp. 255-262, Dec. 2018, doi: 10.1016/j.solmat.2018.09.011.

[27] M. A. Moghimi and G. Ahmadi, "Wind barriers optimization for minimizing collector mirror soiling in a parabolic trough collector plant," Applied Energy, vol. 225, no. April, pp. 413-423, 2018, doi: 10.1016/j.apenergy.2018.05.027.

[28] Y. Jiang, L. Lu, and H. Lu, "A novel model to estimate the cleaning frequency for dirty solar photovoltaic (PV) modules in desert environment," Solar Energy, vol. 140, pp. 236-240, 2016, doi: 10.1016/j.solener.2016.11.016.

[29] A. Rao, R. Pillai, M. Mani, and P. Ramamurthy, "Influence of dust deposition on photovoltaic panel performance,” Energy Procedia, vol. 54, pp. 690-700, 2014, doi: 10.1016/j.egypro.2014.07.310.

[30] A. A. Babatunde, S. Abbasoglu, and M. Senol, "Analysis of the impact of dust, tilt angle and orientation on performance of PV Plants," Renewable and Sustainable Energy Reviews, vol. 90, no. May 2017, pp. 10171026, 2018, doi: 10.1016/j.rser.2018.03.102.

[31] H. Lu, L. Lu, and Y. Wang, "Numerical investigation of dust pollution on a solar photovoltaic (PV) system mounted on an isolated building," Applied Energy, vol. 180, pp. 27-36, Oct. 2016, doi: 10.1016/j.apenergy.2016.07.030.

[32] H. Lu and L.-Z. Zhang, "Influences of dust deposition on ground-mounted solar photovoltaic arrays: A CFD simulation study," Renewable Energy, vol. 135, pp. 21-31, May 2019, doi: 10.1016/j.renene.2018.11.096.

[33] H. Heydarabadi, M. Abdolzadeh, and K. Lari, "Simulation of airflow and particle deposition settled over a tilted Photovoltaic module,” Energy, vol. 139, pp. 1016-1029, 2017, doi: 10.1016/j.energy.2017.08.023.

[34] H. Lu and W. Zhao, "CFD prediction of dust pollution and impact on an isolated ground-mounted solar photovoltaic system," Renewable Energy, vol. 131, pp. 829-840, 2019, doi: 10.1016/j.renene.2018.07.112.

[35] B. Mahmoodi, S. H. Hosseini, and G. Ahmadi, "CFD-DEM simulation of a pseudo-two-dimensional spouted bed comprising coarse particles," Particuology, vol. 43, pp. 171-180, Apr. 2019, doi: 10.1016/j.partic.2017.12.014.

[36] M. A. Moghimi, A. Rungasamy, K. J. Craig, and J. P. Meyer, "Introducing CFD in the optical simulation of linear Fresnel collectors," AIP Conference Proceedings, vol. 1734, no. 1, p. 020015, May 2016, doi: 10.1063/1.4949039.

[37] P. Karava, C. M. Jubayer, and E. Savory, "Numerical modelling of forced convective heat transfer from the inclined windward roof of an isolated low-rise building with application to photovoltaic/thermal systems," Applied Thermal Engineering, vol. 31, no. 11, pp. 1950-1963, Aug. 2011, doi: 10.1016/j.applthermaleng.2011.02.042.

[38] F. R. Menter, "Two-equation eddy-viscosity turbulence models for engineering applications," AIAA Journal, vol. 32, no. 8, pp. 1598-1605, Aug. 1994, doi: 10.2514/3.12149. 
[39] L. Zhu, A. Li, and Z. Wang, "Analysis of particle trajectories in a quick-contact cyclone reactor using a discrete phase model," Separation Science and Technology, vol. 53, no. 6, pp. 928-939, Apr. 2018, doi: 10.1080/01496395.2017.1386683.

[40] M. W. Heggøy, "Numerical Investigation of Particle Dispersion in a Gravitational Field and in Zero Gravity.," Master of Science Thesis, 2017, [Online]. Available: The University of Bergen, Department of Physics and Technology.

[41] B. Zhao, Y. Zhang, X. Li, X. Yang, and D. Huang, "Comparison of indoor aerosol particle concentration and deposition in di erent ventilated rooms by numerical method," vol. 39, pp. 1-8, 2004, doi: 10.1016/j.buildenv.2003.08.002.

[42] S. Liu, W. Pan, X. Cheng, H. Zhang, Z. Long, and Q. Chen, "CFD Simulations of Wind Flow in an Urban Area with a Full-scale Geometrical Model," 4th International Conference On Building Energy, Environment, p. 6, 2018.

[43] X. Zhang, "CFD simulation of neutral ABL flows," Risø DTU National Laboratory for Sustainable Energy. Technical University of Denmark, Roskilde, Denmark. (Risø-R_1688 (EN), p. 42, 2009.

[44] A. Abiola-Ogedengbe, H. Hangan, and K. Siddiqui, "Experimental investigation of wind effects on a standalone photovoltaic (PV) module," Renewable Energy, vol. 78, pp. 657-665, 2015, doi: 10.1016/j.renene.2015.01.037.

[45] Y. Tominaga, S. ichi Akabayashi, T. Kitahara, and Y. Arinami, "Air flow around isolated gable-roof buildings with different roof pitches: Wind tunnel experiments and CFD simulations," Building and Environment, vol. 84, pp. 204-213, 2015, doi: 10.1016/j.buildenv.2014.11.012.

[46] C. G. Justus and A. Mikhail, "Height variation of wind speed and wind distributions statistics," Geophysical Research Letters, vol. 3, no. 5, pp. 261-264, May 1976, doi: 10.1029/GL003i005p00261.

[47] J. Twidell and T. Weir, Renewable energy resources, Third edition. London; New York: Routledge, Taylor \& Francis Group, 2015.

[48] S. V. Klinkov, V. F. Kosarev, and M. Rein, "Cold spray deposition: Significance of particle impact phenomena," Aerospace Science and Technology, vol. 9, no. 7, pp. 582-591, Oct. 2005, doi: 10.1016/j.ast.2005.03.005.

[49] X. Li, P. F. Dunn, and R. M. Brach, "experimental and numerical studies of microsphere oblique impact with planar surfaces," Journal of Aerosol Science, vol. 31, no. 5, pp. 583-594, May 2000, doi: 10.1016/S0021-8502(99)00544-3.

[50] X. Li, P. F. Dunn, and R. M. Brach, "Experimental and numerical studies on the normal impact of microspheres with surfaces," Journal of Aerosol Science, vol. 30, no. 4, pp. 439-449, Apr. 1999, doi: 10.1016/S0021-8502(98)00067-6.

[51] H. Lu and W. Zhao, "Effects of particle sizes and tilt angles on dust deposition characteristics of a groundmounted solar photovoltaic system," Applied Energy, vol. 220, pp. 514-526, Jun. 2018, doi: 10.1016/j.apenergy.2018.03.095. 